\title{
НОРМИ ЕТИКЕТНОГО СПІЛКУВАННЯ В МЕТОДИЦІ ВИКЛАДАННЯ ІНОЗЕМНИХ МОВ
}

Коробка Г. О. Норми етикетного спілкування в методиці викладання іноземних мов.

У статті досліджено різні норми етикетного спілкування. Проаналізовано фатичну функцію мови, спрямовану на встановлення й підтримку контакту у процесах спілкування. 3'ясовано, що мовний етикет слугує підтримкою контакту між людьми, є головним чинником фатичного спілкування. У цьому аспекті людина розглядається як продукт і результат спілкування, акцентується на інтерсуб'єктивному в мовному етикеті.

Ключові слова: етикетне спілкування, мова, мовний етикет, фатичне спілкування, комунікація.

Коробка Г.А. Нормы этикетного общения в методике преподавания иностранных языков.

В статье исследуются различные нормы этикетного общения. Анализируется фатическая функция языка, направленная на установление и поддержку контакта в процессах общения. Установливается, что речевой этикет используется для поддержания контакта между людьми, является главным фактором фатического общения. В этом аспекте человек рассматривается как продукт и результат общения, акцентируется на интерсубъективном в речевом этикете.

Ключевые слова: этикетное общение, язык, речевой этикет, фатическое общение, коммуникация.

Korobka H. O. Norms of Etiquette Communication in Foreign Language Teaching.

The article investigates various norms of etiquette communication. The phatic function of the language is examined, aimed at establishment and mutual support of the contact in communication process. It is specified that speech etiquette is used for support of the contact among people, i.e. it is the major factor of the phatic communication. In this aspect a human is a product and a result of communication with other people, i.e. as intersubjective creature of language in speech etiquette.

Key words: etiquette communication, language, speech etiquette, phatic communication, communication.

Мова, як засіб щоденного спілкування людей, перебуває у процесі постійного розвитку. За своєю суттю вона є чимось постійним, але водночас змінним. Постійний розвиток - основа функціонування мови. Історія мовного становлення пов'язана 3 філософським осмисленням світу й дійсності людиною. Мова $є$ інтерпретацією реальності, тому мовознавство історично пов'язане 3 філософією і лінгвофілософією. 
Сучасний етап розвитку мовознавства характеризується посиленням інтересу дослідників до комунікативного аспекту мови та ії реалізації у процесі мовного спілкування. Тому слід визнати необхідність і важливість вивчення не просто функціонування мови, але і їі активної комунікативної ролі в людському суспільстві, оскільки комунікація людей - основа їхньої свідомості, пізнання й буття загалом. Людина не може існувати без комунікації, іiї суть значною мірою визначається в етикетному спілкуванні 3 іншими людьми. Система i лад мови вивчаються в межах комплексного і багатоаспектного підходу з позиції функціонально-динамічних аспектів мовних феноменів із урахуванням психологічних характеристик комунікантів, їх місця і ролі в соціумі. Отже, мова не тільки певний критерій інтелектуального, морального розвитку людини, iї загальної культури, а й інструмент світосприйняття. У комунікації як дискурсі, де відбивається здоровий глузд людини, індивіди можуть обговорювати, констатувати й обгрунтовувати різні норми й цінності життя в сучасному суспільстві.

Етикет і мова тісно пов'язані. Мовний етикет словесно передає етикет поведінки, репрезентує ті мовні багатства, що накопичилися в кожному суспільстві для вираження неконфліктного, нормального ставлення до людей, а це означає - доброзичливість. Філософи і лінгвісти дискутують щодо зародження комунікативної (дискурсивної) етики та філософії, яка, на думку сучасного українського філософа А. Срмоленка, спрямована на розв'язання методологічних, практичних проблем i питань сучасності, що грунтуються на філософствуванні, а відтак, i на методологічному принципі, повсякденному мовному спілкуванні між людьми [3, с. 9]. Мета статті - дослідити різні норми етикетного спілкування у процесі викладання іноземних мов.

До проблеми співвідношення етикету й мови зверталися чимало науковців, 3-поміж яких вирізняються праці В. Гольдіна. Дослідник кваліфікує етикет як «один з численних засобів спілкування, що використовується людьми. Порівняння його 3 головним засобом людського спілкування - мовою - дає змогу краще розібратися не тільки в етикеті, але й у самій мові. У мові безпосередньо виражаються думка, людська свідомість; крім того, мова універсальна: складно назвати умови, у яких не можна було б нею скористатися» $[2$, с. 4,8$]$. У своїй сфері знаки етикету також зручні. Спілкуючись 3 (С Г. О. Коробка, 2015. 
людьми, ми так чи так оцінюємо стосунки з ними, регулюємо їх. Це і $є$ тією особливою сферою, у якій використовуються засоби етикету й для якої вони призначені. У спеціальних лексикографічних працях, скажімо, у словниках з етики, етикет (фр. etiquette - ярлик, етикетка) кваліфікується так: сукупність правил поведінки, що стосуються ставлення до людей (поводження з оточуючими, форм звертання i вітань, поведінки у громадських місцях, манер й одягу).

Мова відіграє вирішальну роль у процесах соціалізації людини. Соціально визначені ситуації потребують функціонально певних знаків. Особистість у процесі соціалізації засвоює як необхідність (звичку, звичай, ритуал) використання знаків, що вказують на ставлення до співрозмовника, уможливлюють установлення контакту уваги в потрібному спрямуванні відповідно до стосунків людей, які спілкуються, умов спілкування і багатьох інших соціально (суспільно й особистісно) зумовлених факторів. Мовний етикет, як відомо, пропонує мовцям використання певних формул залежно від ситуації спілкування. Носії мови, що опанували правила мовного узусу в процесі соціалізації, інтуїтивно здійснюють вибір необхідних одиниць, орієнтуючись на екстралінгвальні умови, серед яких особливе значення має ступінь офіційності обстановки і відносин між комунікантами.

Етикетне спілкування як комплексне явище - об'єкт вивчення різних наук i наукових напрямів, зокрема соціолінгвістики, лінгвокраїнознавства тощо, тому має посісти відповідне місце у власне лінгвістичних наукових працях й особливо методичних розробках. Постійні характеристики (константи) мовної свідомості та комунікативної (етикетної) поведінки визначають тип особистості, групи й етноси і в цьому сенсі є домінантами свідомості та поведінки. Саме вони в концентрованому вигляді виражаються як аксіологічні явища культури, систематичне осмислення яких у мові дає змогу виокремити етикетну лінгвістику в лінгвофілософському напрямку. У мовному етикеті виразніше, ніж в інших функціонально-семантичних мікросистемах, виявляється «людський фактор» - принцип антропоцентризму, пов'язаний зі специфікою ситуативної, семіотичної, граматичної, семантичної природи одиниць.

Серед комунікативних систем i підсистем важливу роль відіграють національно-специфічні правила поведінки, як мовної, так і немовної, пов'язані з семіотичним поняттям етикету. Етикет, зокрема 
мовний, репрезентує в акті комунікації безліч соціально значущих позицій: і ступінь знайомства / незнайомства комунікантів, рівність / нерівність їх у ситуації спілкування тощо, тобто всі прийняті в певному соціумі норми мовної поведінки. Знання цих національноспецифічних правил «мови повсякденної поведінки» так само важливе для спілкування, як і власне мовні правила для побудови мови. Тому комунікативний принцип викладання іноземної мови передбачає не тільки навчання різних видів мовної діяльності за умови знання законів побудови та використання комунікативних одиниць, уміння продукувати вільні висловлювання і репродукувати стійкі формули, а й розуміння законів етикетного спілкування мовою. Формули мовного етикету, які реалізуються в певній ситуації, типізовано відображають цю ситуацію, १ї компоненти, що набувають утілення в семантичній і граматичній структурі одиниць, а також в стилістичних конотаціях. При цьому ситуація конкретної, окремої одиниці відображає властивості узагальнених ситуацій усього мовного етикету. Мовний етикет має такі ознаки:

1) наявність адресанта й адресата;

2) засіб зв'язку (код) - спеціалізовані стійкі формули;

3) соціально запропонована форма етикетної поведінки;

4) мотив-потреба (необхідність, повинність, бажаність) використати одиницю мовного етикету для долучення до контакту і підтримки спілкування;

5) мета - створити бажану тональність спілкування;

6) контактний (рідше - дистантний) стан комунікантів $[5$, с. $4,17-18]$.

Якщо йдеться про виокремлення мовного етикету як особливого об'єкта лінгвістичного та методичного дослідження, доцільно, на нашу думку, зважати на взаємопов' язані й близькі, однак різні поняття:

a) сферу застосування мовного етикету;

б) сферу вживання одиниць мовного етикету.

Ці поняття останнім часом перебуває під пильною увагою лінгвістів та методистів, які вивчають теорію комунікації - 3 екстралінгвальними характеристиками комунікантів і ситуації спілкування, що визначають як вибір одиниць та особливості їх функціонування в мові, так i внутрішні властивості таких одиниць [5, с. 8].

Серед найважливіших функцій мови лінгвісти і філософи, (С Г. О. Коробка, 2015. 
виокремлюють символічну (мова уявляється як складний світ символів, що забезпечують функціонування людського суспільства i на яких грунтуються явища культури), комунікативну (спосіб спілкування 3 іншими людьми, колективами, інституціями), когнітивну (пізнавальну, гносеологічну, пов'язану 3 мисленням), емотивну, або експресивну (спосіб вираження почуттів, емоцій), метамовну (спосіб дослідження мови в термінах самої мови), естетичну (мова як носій категорій прекрасного і потворного), магічну (мова як спосіб упливу на світ та інших людей, зазвичай, без їхнього відома).

3 основними функціями мови пов'язані і другорядні (похідні), зокрема: 3 комунікативною - фактична, спрямована на встановлення i підтримку контакту між адресантом та адресатом у процесах спілкування; конотативна, що полягає в осмисленні й засвоєнні інформації під час спілкування; волюнтативна, за допомогою якої людина здійснює вплив i волевиявлення у процесах взаємодії; кумулятивна, або історико-культурна, яка $є$ основою збереження культурно-історичної спадщини народу.

Уперше звернув увагу на неминучість спілкування в гостях (або необхідне етикетне спілкування) англійський етнограф Б. Маліновський [4], який назвав цей рівень спілкування фатичним, тобто «контактоналагоджувальним». Фатичне спілкування стало предметом дослідження лінгвістів, які добирають типове коло тем, особливості тексту, учасників спілкування тощо. Надзвичайно актуальна ця тематика для фахівців із викладання іноземних мов, тому що під час навчання мови важливо навчити, як правильно «вступити» в мовний контакт і як його підтримувати. В іншому разі людина, знаючи саму систему мови, буде неспроможною в багатьох життєвих ситуаціях, які, відповідно, можуть виявитися навіть комічними для неї.

Дійсно, етикет виявляється в різних аспектах життя людини, і комунікативна функція мови є основою формування їі комунікативної поведінки - вербальної (мовної) і супутньої невербальної (жестів, міміки, поз, інтонації, пауз, зітхання тощо) - або групи людей, які регулюють норми і традиції спілкування соціуму. Найважливішу роль в етикетному вираженні ставлення до людей відіграє мова. В етикеті існують вербальні та невербальні засоби [2, с. 43, 45]. За допомогою мови нескладно повідомити про те, про що інформують невербальні засоби етикету, а етикетні знаки не передають. I справа не стільки в 
тому, що етикет як засіб спілкування «слабший» за людську мову, скільки в тому, що вони мають різну спрямованість. Етикет спрямований на полегшення орієнтації в суспільстві, і його знаками відзначаються не всі, а лише загальноприйняти стосунки. Якщо мова представляє відносини в усій їх складності та конкретності, диференціюючи другорядне i суттєве, швидкоплинне i стійке, то етикет акцентує лише на основному. Але і це здійснюється мовою етикету не так, як мовою слів. На відміну від мовних повідомлень послання «мовою етикету» передають ситуацію нерозчленовано, загалом не виокремлюючи складників. Етикет не виражає понять, не називає ситуацій, але, маніфестуючи людські взаємини, передає і наші уявлення про них.

У різних народів комунікативна поведінка може істотно відрізнятися, ускладнюючи міжкультурні комунікації, і може стати причиною культурного шоку. Способи реалізації в різних культурах фатичної функції мови також різні. Наприклад, у мовному етикеті різних народів є суттєві відмінності в тематиці спілкування (у гостях і на роботі); у різних культурах відрізняються комунікативні ролі посмішок, сміху, оплесків, рукостискання, поцілунків тощо. Мовний етикет відображає особливий рівень інформації, якою ми обмінюємося під час спілкування. Мовознавці виявили, що в мові наявна система словесних пестощів. Важливе місце належить тут мовному етикету, оскільки в запитаннях про життя, здоров'я, справи, у подяках, вибаченнях, привітаннях і вітаннях, побажаннях і т. ін. міститься потреба висловити симпатію стосовно іншої людини, а отже, мовний етикет уможливлює підтримання контакту між людьми, є головним фактором фатичного спілкування. Наприклад:

«-Привіт, як справи?

- Усе гаразд! А в тебе?

- Теж нічого. Ну, бувай!

- Бувай!»

Так відбувається обмін контактними фразами. Мовний етикет реалізується в ситуації безпосереднього спілкування, коли «тут» (у точці зустрічі) i «зараз» (у момент зустрічі) учасники фатичного спілкування (Я-Ти) безпосередньо обмінюються вітаннями, зазвичай супроводжуючи їх посмішкою, адже посмішка $є$ показником зв'язку Я-Ти, який, своєю чергою, є зв'язком-комунікацією в лінгвофілософії.

(С Г. О. Коробка, 2015. 
Без цього зв'язку неможливе людське спілкування. Найчастіше в англо- й американомовних етикетних ситуаціях спілкування привітальні фрази-кліше слід вимовляти 3 посмішкою і гарним настроєм, незалежно від того, яке самопочуття в людини насправді. Тут наявна ситуація приховування чи непоширення реального стану справ, т. зв. відмежованості від дійсності, оскільки висловлювання мовного етикету стосуються особистісних тем та скорочують дистанцію учасників спілкування.

У зв'язку 3 темою етикету англомовного суспільства інтерес становить питання про дистанцію, що розділяє учасників спілкування. Так, на думку Е. Холла [4], розрізняють чотири основні типи дистанції: інтимна, персональна, соціальна та публічна, що значно впливають на поведінку людини. Інтимна дистанція (до 0,5 м) - це емоційно заряджена зона, яка використовується для прояву любові, захисту, утіхи під час спілкування між найближчими людьми; персональна дистанція (від 0,5 до 1,2 м) характерна для неформальних контактів між друзями; соціальна дистанція (від 1,2 до 3,5 м) - це звичайна відстань між знайомими, а іноді й незнайомими людьми під час ділової бесіди, шкільного уроку тощо; публічна дистанція (від 3,5 м і далі) характерна для одностороннього спілкування лектора 3 аудиторією й потребує підвищення голосу, стилізації жестів і чіткішої вимови. Необхідно зауважити, що дистанція між учасниками спілкування значною мірою залежить від національно-культурних особливостей країни або регіону. Описані вище особливості характеризують англомовне суспільство, і жодним чином не можуть застосовуватися, наприклад, до латиноамериканців, які зазвичай розмовляють один 3 одним на ближчій відстані. Це призводить до певного нерозуміння під час їхнього спілкування 3 громадянами США: північноамериканці інстинктивно віддаляються під час розмови, а в латиноамериканців складається враження, що громадяни США - холодні й неприязні. Так чи так використання фраз-кліше мовного етикету у привітальних ситуаціях зумовлює виникнення стану радості, що сприяє приділенню уваги учасникові комунікативної ситуації. «Дякую вам!» - у фразі, іiі структурі, граматиці, семантикою відбиті «я» і «ти», фраза прирівнюється до доброго вчинку «тут» i «зараз». Інформація $є$ соціальною і передає конотативний сенс фраз «я тебе помічаю, поважаю, контактую 3 
тобою, бажаю тобі добра». За своїм походженням висловлювання мовного етикету (у своїй етимології) означають доброзичливість: здрастуйте, вітаю - будьте здорові; дякую; вибачте - визнаю свою провину $і$ прошу пробачити; спасибі- спаси Бог (за добрі справи) тощо [4]. Як зазначено вище, етикет як сукупність загальноприйнятих, упорядкованих правил (норм) стандартизує поведінку людей у типових ситуаціях, регулює відносини між ними, являє собою зовнішню культуру спілкування.

Можна вважати, що донині в методиці викладання іноземних мов склалося чітке уявлення про те, що без урахування лінгвокраїнознавчого аспекту неможливі адекватне засвоєння культурних цінностей країни досліджуваної мови, успішне оволодіння іноземною мовою, специфікою узуальної мовної поведінки. Типові помилки тих, хто вивчає іноземну мову, у мовному етикеті численні, вони є переважно узуальними й пов'язані з інтерференцією. Мовний етикет належить до фонових знань тих, хто говорить цією мовою, тому опанування такої системи необхідне для адекватного спілкування «інокультурних» комунікантів [5, с. 110-111].

Зазначимо, що в межах однісї статті неможливо розглянути всі норми етикетного спілкування. Проте очевидно, що формульні моделі поведінки й етикетно значущі ознаки, які відображають національноспецифічні норми поведінки, заслуговують на увагу, вивчення та пояснення у процесі викладання іноземних мов, а отже, слугують перспективою подальших лінгвофілософських досліджень у межах комплексного підходу до цієї теми.

\section{Література}

1. Бацевич Ф. Духовна синергетика рідної мови : Лінгвофілософські нариси : [монографія] / Ф. Бацевич. - К. : ВЦ «Академія», 2009. - 192 с.

2. Гольдин В. Е. Речь и этикет / В. Е. Гольдин. - М. : Просвещение, 1983. -109 с.

3. Єрмоленко А. М. Комунікативна практична філософія / А. М. Єрмоленко. - К. : Лiбра, 1999. - 488 c.

4. Речевой этикет и вежливость сегодня [Электронный ресурс] - Режим доступа : http://www.xserver.ru/user/reets/2.shtml. - Загл. с экрана.

5. Формановская Н. И. Русский речевой этикет : лингвистический и методический аспекты / Н. И. Формановская. - М. : Русский язык, 1982. - 126 с.

Стаття надійшла до редакиії 22.12.2014 p.

(С Г. О. Коробка, 2015. 